\title{
MOLECULAR CHARACTERIZATION AND PHYLOGENETIC ANALYSIS OF AVIAN POX VIRUS ISOLATED FROM PET BIRDS AND COMMERCIAL FLOCKS, IN IRAN
}

\author{
Arash Ghalyanchilangeroudi', Hossein Hosseini2*, Rima Morshed ${ }^{3}$ \\ ${ }^{1}$ Department of Microbiology and Immunology, Faculty of Veterinary Medicine, University of Tehran, Tehran, ${ }^{2}$ Department of Clinical \\ Sciences, Faculty of Veterinary Medicine, Karaj Branch, Islamic Azad University, Karaj, ${ }^{3}$ Agriculture and Veterinary group, Iran Encyclopedia \\ Compiling Foundation, Ministry of science, research and technology, Tehran, Iran \\ *Corresponding author, E-mail: hosseini.ho@gmail.com
}

\begin{abstract}
Avian pox (AP) is a viral disease with a wide host range. The aim of the study was molecular identification and characterization of field isolated pox virus from pet birds and commercial flocks in Iran, by polymerase chain reaction (PCR). Scab materials of skin and mucosal lesions were collected from five clinically affected cases. PCR was used to amplify a 578 bp fragment of the poxvirus $4 \mathrm{~b}$ core protein. In order to determine the genetic relationships among the viruses, this conserved poxvirus genetic region was sequenced and analyzed. The Iranian Avipoxvirus isolates in this study grouped in clade A1 (commercial chicken and turkey flocks) and B1 (canary). Further studies on a larger scale need to be developed to have a better understanding of the molecular characterization of the Iranian APV strains.
\end{abstract}

Key words: avian pox; phylogenetic analysis; molecular characterization; Iran

\section{Introduction}

Avian Pox (AP) is a viral well-known disease in hens, turkeys and many other birds (278 species from 70 families and 23 orders), characterized by cutaneous lesions on the feather-less skin and/or diphtheritic lesions of mucous coats of the upper alimentary and respiratory tract. Moreover, concurrent systemic infection causing high mortality often occurs in canaries. AP lesions, however, may compromise vision, the ability to feed or lead to secondary bacterial or

Received: 13 February 2016

Accepted for publication: 19 November 2018 fungal infection leaving wild birds vulnerable to predation. The poxviruses which infect birds belong to the genus Avipoxvirus of the Poxviridae family. Avipoxviruses (APVs) within the family Poxviridae contain nearly 300-kilo base pair (kbp) of doublestranded DNA that replicate in the cytoplasm of infected cells and the members of the genus Avipoxvirus in the subfamily chordopoxvirinae (1). Pox infection usually occurs through the mechanical transmission of the virus to injured skin and also the bite of mosquitoes or mites. The incubation period and duration of APV infection is variable (from a few days to many months), but affected birds with mild lesions frequently recover and this is considered to be the most common 
situation in wild birds. Its incidence is variable in different areas because of differences in climate, management and hygiene or the practice of regular vaccination. It can cause drops in egg production, or retarded growth in younger birds (2).

The conventional laboratory diagnosis of APV is carried out by histopathological examination, electron microscopy, virus isolation on chorioallantoic membrane (CAM) of embryonated chicken eggs or cell cultures, and serologic methods (2). The $4 \mathrm{~b}$ core protein gene $(\mathrm{p} 4 \mathrm{~b})$ of APV that encodes the protein with molecular weights of 75.2 $\mathrm{kDa}$ is usually chosen for comparative genetic analysis $(3,4,5)$. Also, amplification of the $\mathrm{p} 4 \mathrm{~b}$ of APV by PCR has often been used as a molecular tool for the detection of APVs (6). PCR in combination with restriction endonuclease enzyme analysis (REA) followed by sequence analysis of the amplified fragments is used for detection, differentiation and molecular characterization of fowl pox virus isolates (7). Even considering the decrease in problems caused by poultry production, avian pox is still a significant pathogen which can have serious effects on wild Galliformes. The incidence of AP in Iran is high in pet birds and also in fewer levels in commercial farms. In recent years, some outbreaks of skin lesions suspected to be avian pox were observed in the backyard poultry in different parts of western areas in Iran. Generally, the number of reports concerning incidence and characterization of avian pox viruses in Iran is very low. Gholami-Ahangaran et al. performed a survey on 328 backyard poultries with suspected signs of avian pox virus infection. Their results showed 217 and 265 out of 328 samples were positive for avian pox virus on histopathological and PCR examination, respectively (8). In the study of Fasaei et al. (2014), Avipoxvirus specific DNA was detected in all 10 different isolates from chicken, canary and mynah that were collected from Tehran province (3). The aim of this study was a characterization of AFPv isolates from canary, chicken and turkey flocks by PCR.

\section{Materials and methods}

\section{Sampling}

Samples (cutaneous scrub and caseous lesions) were collected from different species with characteristic clinical signs $(5$ samples from chicken, canary, turkey) had been submitted to PCR Veterinary Diagnostic Laboratory (Tehran, Iran), during 2012-2014. The data of samples are available in table 1.

\section{DNA extraction}

DNA was extracted from the skin or pulmonary lesions of the clinical cases and lyophilized vaccines (as a positive control) by QIAamp DNAMini Kit (Qiagen) following the manufacturer's guidelines. DNA samples were stored at $-20^{\circ} \mathrm{C}$ until analysis.

\section{Amplification of $4 b$ Gene}

The AVP-specific PCR was performed using primer pairs described based on FPV 4b core protein (P4b) gene sequence of Fowl pox virus strain HP444 previously (9). The sequence of the primers was as follows: forward primer: 5'-CAGCAGGTGCTAAACAACAA and reverse primer: 5'- CGGTAGCTTAACGCCGAATA. PCR consisted of 25 $\mu 1$ reaction containing 1.5 units of Taq DNA polymerase, $1.5 \mathrm{mM} \mathrm{MgCl} 2,200 \mu \mathrm{M}$ of each deoxynucleoside triphosphate, $6 \mathrm{pmol}$ of each primer, DNA extracted from clinical samples and nuclease free water up to $25 \mu 1$. Amplification was performed after initial denaturation for $2 \mathrm{~min}$ at $94^{\circ} \mathrm{C}$ for $35 \mathrm{cy}$ cles and consisted of $1 \mathrm{~min}$ denaturation at $94^{\circ} \mathrm{C}$, $1 \mathrm{~min}$ annealing at $60^{\circ} \mathrm{C}$, and $1 \mathrm{~min}$ extension at $72^{\circ} \mathrm{C}$. In this study, live fowl pox vaccine (Razi Vaccine and Serum Research Institute, Iran) was provided and used as positive control.Negative control includes all the reagents without a template.

\section{Sequencing and Phylogenetic analysis}

The positive PCR products were analyzed by electrophoresis on a $1 \%$ agarose gel and visualized bye GelRed ${ }^{\mathrm{TM}}$ (Biotium, USA) staining and ultraviolet transillumination. The PCR products were purified by the PCR AccuPrep ${ }^{\circledR}$ PCR Purification Kit (Bioneer Co., Korea) and purified PCR products were sent for sequencing (Source Bioscience, UK) with PCR primers for in a forward and in a reverse direction. Sequencing reactions were run on an ABI Prism 310 Genetic Analyzer. The sequence results were downloaded and analyzed using Chromas (Technelysium Pry Ltd., Australia). Phylogenetic analysis was carried out by analyzing the data obtained here with those of other sequences of FPVs 
from the GenBank database. The phylogenetic analysis was performed with the MEGA5 (Phylogeny Inference Package) software, version5. Distancebased neighbor-joining trees were constructed using the Tamura-Nei model (10). The robustness of the phylogenetic trees was assessed by 1,000 bootstrap replicates. Bootstrap values lower than 50 were omitted. The FPV sequences tested in this study were deposited in GenBank under accession numbers KT003286 -KT003290.

\section{Results}

Because of the highly conserved nature of the analyzed genes, nucleotide sequences rather than amino acid sequences were used to determine divergence. Clades and sub clades have been named according to previous APV phylogenetic studies based on the P4b (11). The strains were placed in A1 and B1 sub clades. The homology between isolates was $67.3 \%-100 \%$ (Table 3).

Table 1: Description of fowl pox virus strains investigated in this study

\begin{tabular}{|l|l|l|l|l|l|l|}
\hline Strain name & Nam in Tree & Species & Type of Lesion & Year & Province & $\begin{array}{l}\text { Accession } \\
\text { No. }\end{array}$ \\
\hline $\begin{array}{l}\text { IR/Canary poxvirus/ } \\
\text { H364/12 }\end{array}$ & CP/H364/12 & Canary & Cutaneous & 2012 & Alborz & KT003286 \\
\hline $\begin{array}{l}\text { IR/Canary poxvirus/ } \\
\text { H913/14 }\end{array}$ & CP/H913/14 & Canary & Cutaneous & 2014 & Kurdistan & KT003287 \\
\hline IR/Fowl pox virus/H252/12 & FP/H252/12 & Chicken & Caseous & 2012 & Isfahan & KT003288 \\
\hline IR/Fowl pox virus/H756/13 & FP/H756/13 & Chicken & Caseous & 2013 & Tehran & KT003289 \\
\hline $\begin{array}{l}\text { IR/Turkey pox virus/ } \\
\text { H335/12 }\end{array}$ & TP/H335/12 & Turkey & Cutaneous & 2012 & Alborz & KT003290 \\
\hline
\end{tabular}

Table 2: Details of poxvirus sequences obtained from GenBank

\begin{tabular}{|c|c|c|c|c|c|}
\hline Isolate name & Abbreviation (Tree) & Host & Country & $\begin{array}{c}\text { Accession } \\
\text { Number }\end{array}$ & Clades \\
\hline Fowlpox virus isolate FPV-VR250 & FP/FPV-VR250 & Chicken & Norway & AY453172 & A1 \\
\hline Fowlpox virusNobilis Variole W (Intervet) & FP/ Nobilis Variole W & Chicken & United Kingdom & AM050379 & A1 \\
\hline Fowlpox Mild (Websters; Fort Dodge) & FP/Websters Mild & Chicken & United Kingdom & AM050378 & A1 \\
\hline Avipoxvirus isolate GB 134/01 & TP/ GB 134 & Turkey & Germany & AY530304 & A1 \\
\hline FWPVD Diftosec CT (Merial) & FP/ Diftosec CT & Chicken & United Kingdom & AM050380 & A1 \\
\hline pigeonpox PGPV TP-2 & $\mathrm{PP} / \mathrm{TP}-2$ & Pigeon & Germany & AY530303 & $\mathrm{A} 2$ \\
\hline Avipoxvirus isolate CVL 2/11/66 & TP/ CVL 66 & Turkey & United Kingdom & AM050387 & A2 \\
\hline Avipoxvirus isolate CVL 10/12/98 & TP/ CVL 98 & Turkey & United Kingdom & AM050388 & $\mathrm{A} 2$ \\
\hline Avipoxvirus HNPV/NZL/2002 & $\mathrm{PP} / \mathrm{HNPV}$ & Pigeon & New Zealand & HQ701713 & A3 \\
\hline AvipoxvirusCVL 353/87 & AP/CVL 87 & Albatross & United Kingdom & AM050392 & A3 \\
\hline Falconpox FLPV GB362-02 & FLP/ GB362-02 & Falcon & Germany & AY530306 & A4 \\
\hline Canarypox virus isolate CP10IR & CP/CP10IR & Canary & Iran & KC193679 & B1 \\
\hline Canarypox virus isolate Yazd 1 & $\mathrm{CP} / \mathrm{Yazd} 1$ & Canary & Iran & KF673397 & B1 \\
\hline Canarypox virus strain AT_Canarypox/1839/2009 & $\mathrm{CP} / 1839$ & Canary & Austria & GU108510 & B1 \\
\hline anarypox virus isolate D98-11133 & $\mathrm{CP} / \mathrm{D} 98-11133$ & Canary & Canada & GQ487567 & B1 \\
\hline Avipoxvirus CVL & $\mathrm{SP} / \mathrm{CVL}$ & Sparrow & United Kingdom & AM05038 & B1 \\
\hline Pigeonpox PPV-B7 & PP/PPV-B7 & Pigeon & Norway & AY453177 & B2 \\
\hline Parrot pox $364 / 89$ & $\mathrm{PP} / 364 / 89$ & Parrot & United Kingdom & AM050383 & $\mathrm{C}$ \\
\hline Avipoxvirus isolate APIII & AP/ APIII & Agapornis & Germany & AY530311 & $\mathrm{C}$ \\
\hline
\end{tabular}




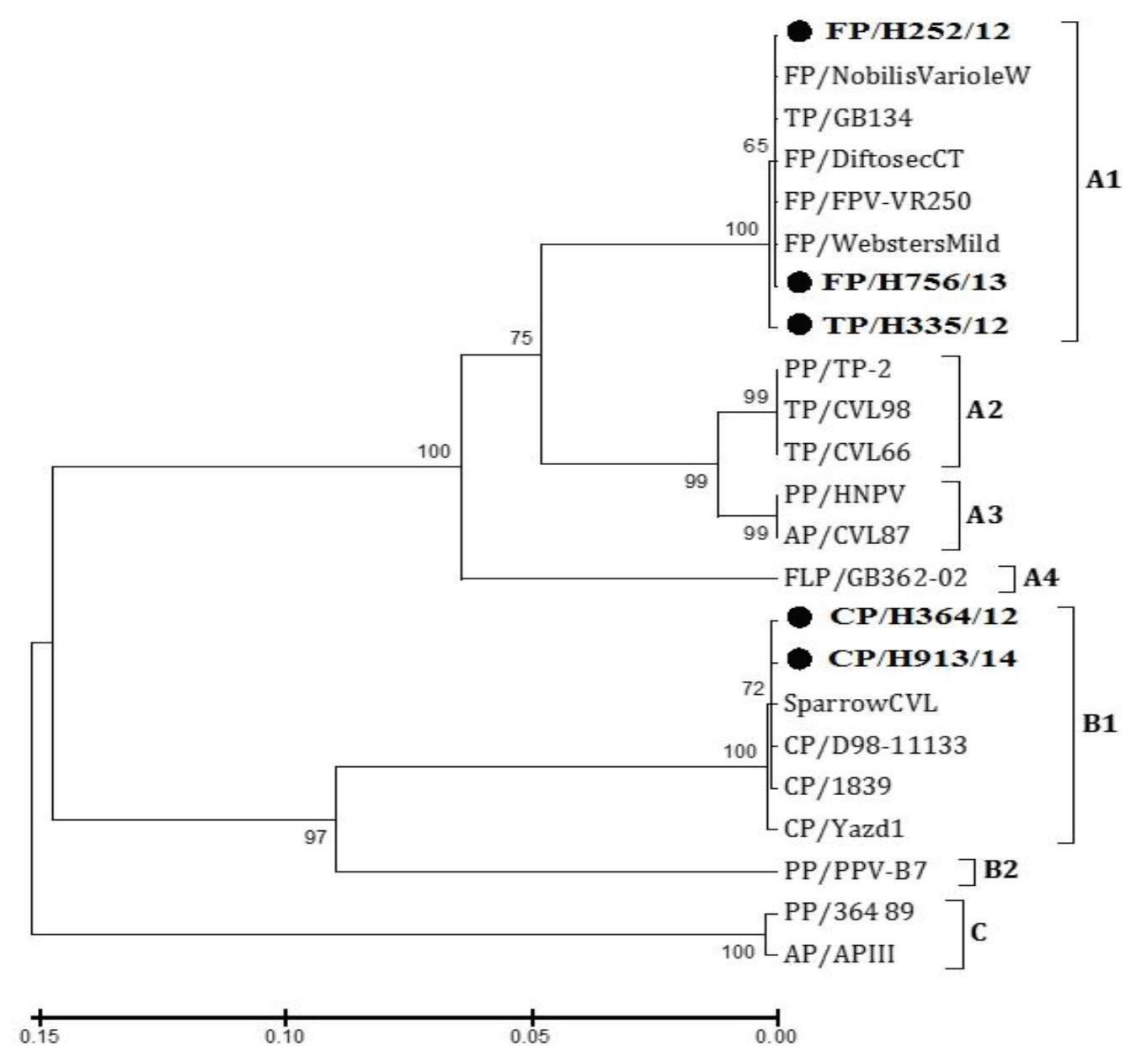

Figure 1: Phylogenetic tree of 578 bp nucleotide sequences of the $4 \mathrm{~b}$ core protein gene of APV isolated in this study (marked with a black circle), reference APV sequences. The tree was obtained by the neighbourjoining method. Bootstrap testing of phylogeny was performed with 1000 replications and values equal to or greater than 70 are indicated on the branches (as a percentage).The length of each bar indicates the amount of evolution along the horizontal branches as measured by substitution per site. APV clades A-C and sub clades are labelled. You could find the details of viruses in tables $1 \& 2$

Table 3: Percentage of $4 \mathrm{~b}$ core protein sequence identity of APV isolated in this study and some selected APV isolates from GenBank

\begin{tabular}{|c|c|c|c|c|c|c|c|c|c|c|c|c|c|c|c|c|c|c|c|c|c|c|c|c|c|}
\hline & & 1 & 2 & 3 & 4 & 5 & 6 & 7 & 8 & 9 & 10 & 11 & 12 & 13 & 14 & 15 & 16 & 17 & 18 & 19 & 20 & 21 & 22 & 23 & 24 \\
\hline 1 & CP/GHPCRLAB.1 & & & & & & & & & & & & & & & & & & & & & & & & \\
\hline 2 & CP/GHPCRLAB.2 & 99.04 & & & & & & & & & & & & & & & & & & & & & & & \\
\hline 3 & FP/GHPCRLAB.3 & 70.26 & 70.91 & & & & & & & & & & & & & & & & & & & & & & \\
\hline 4 & FP/GHPCRLAB.4 & 70.67 & 71.32 & 99.52 & & & & & & & & & & & & & & & & & & & & & \\
\hline 5 & TP/GHPCRLAB.5 & 71.02 & 71.66 & 99.28 & 99.76 & & & & & & & & & & & & & & & & & & & & \\
\hline 6 & TP/GB134 & 70.67 & 71.32 & 99.52 & 100.00 & 99.76 & & & & & & & & & & & & & & & & & & & \\
\hline 7 & FP/WebstersMild & 70.67 & 71.32 & 99.52 & 100.00 & 99.76 & 100.00 & & & & & & & & & & & & & & & & & & \\
\hline 8 & FP/Nobilis VarioleW & 70.67 & 71.32 & 99.52 & 100.00 & 99.76 & 100.00 & 100.00 & & & & & & & & & & & & & & & & & \\
\hline 9 & TP/CVL98 & 70.18 & 70.53 & 89.44 & 90.00 & 89.73 & 90.00 & 90.00 & 90.00 & & & & & & & & & & & & & & & & \\
\hline 10 & FP/DiftosecCT & 70.67 & 71.32 & 99.52 & 100.00 & 99.76 & 100.00 & 100.00 & 100.00 & 90.00 & & & & & & & & & & & & & & & \\
\hline 11 & $\begin{array}{l}\text { FP/FPV-VR250 } \\
\end{array}$ & 70.67 & 71.32 & 99.52 & 100.00 & 99.76 & 100.00 & 100.00 & 100.00 & 90.00 & 100.00 & & & & & & & & & & & & & & \\
\hline 12 & PP/TP-2 & 70.18 & 70.53 & 89.44 & 90.00 & 89.73 & 90.00 & 90.00 & 90.00 & 100.00 & 90.00 & 90.00 & & & & & & & & & & & & & \\
\hline 13 & TP/CVL66 & 70.18 & 70.53 & 89.44 & 90.00 & 89.73 & 90.00 & 90.00 & 90.00 & 100.00 & 90.00 & 90.00 & 100.00 & & & & & & & & & & & & \\
\hline 14 & AP/CVL87 & 69.11 & 69.37 & 90.54 & 91.09 & 90.82 & 91.09 & 91.09 & 91.09 & 97.58 & 91.09 & 91.09 & 97.58 & 97.58 & & & & & & & & & & & \\
\hline 15 & $\mathrm{PP} / \mathrm{HNPV}$ & 69.11 & 69.37 & 90.54 & 91.09 & 90.82 & 91.09 & 91.09 & 91.09 & 97.58 & 91.09 & 91.09 & 97.58 & 97.58 & 100.00 & & & & & & & & & & \\
\hline 16 & FLP/GB362-02 & 70.91 & 71.99 & 86.28 & 86.86 & 86.58 & 86.86 & 86.86 & 86.86 & 87.65 & 86.86 & 86.86 & 87.65 & 87.65 & 87.10 & 87.10 & & & & & & & & & \\
\hline 17 & SparrowCVL & 99.28 & 99.76 & 71.28 & 71.69 & 72.03 & 71.69 & 71.69 & 71.69 & 70.91 & 71.69 & 71.69 & 70.91 & 70.91 & 69.76 & 69.76 & 71.62 & & & & & & & & \\
\hline 18 & CP/D98-11133 & 99.28 & 99.76 & 71.28 & 71.69 & 72.03 & 71.69 & 71.69 & 71.69 & 70.91 & 71.69 & 71.69 & 70.91 & 70.91 & 69.76 & 69.76 & 71.62 & 100.00 & & & & & & & \\
\hline 19 & $\mathrm{CP} / 1839$ & 99.28 & 99.76 & 71.28 & 71.69 & 72.03 & 71.69 & 71.69 & 71.69 & 70.91 & 71.69 & 71.69 & 70.91 & 70.91 & 69.76 & 69.76 & 71.62 & 100.00 & 100.00 & & & & & & \\
\hline 20 & $\mathrm{CP} /$ Yazd 1 & 99.04 & 99.52 & 71.28 & 71.69 & 72.03 & 71.69 & 71.69 & 71.69 & 70.91 & 71.69 & 71.69 & 70.91 & 70.91 & 69.76 & 69.76 & 71.62 & 99.76 & 99.76 & 99.76 & & & & & \\
\hline 21 & $\mathrm{CP} / \mathrm{CP} 10 \mathrm{R}$ & 93.28 & 93.54 & 64.31 & 64.77 & 65.13 & 64.77 & 64.77 & 64.77 & 63.98 & 64.77 & 64.77 & 63.98 & 63.98 & 62.72 & \begin{tabular}{ll|}
62.72 \\
\end{tabular} & 64.27 & 93.80 & 93.80 & 93.80 & 93.54 & & & & \\
\hline 22 & PP/PPV-B7 & 81.26 & 82.15 & 73.29 & 73.69 & 73.36 & 73.69 & 73.69 & 73.69 & 75.15 & 73.69 & 73.69 & 75.15 & 75.15 & 75.15 & 75.15 & 75.88 & 82.15 & 82.15 & 82.15 & 81.83 & 75.12 & & & \\
\hline 23 & $\mathrm{PP} / 36489$ & 71.66 & 71.62 & 70.77 & 71.16 & 71.14 & 71.16 & 71.16 & 71.16 & 69.95 & 71.16 & 71.16 & 69.95 & 69.95 & 69.26 & 69.26 & 67.17 & 71.99 & 71.99 & 71.99 & 71.62 & 65.17 & 72.37 & & \\
\hline 24 & AP/APIII & 70.91 & 70.87 & 70.39 & 70.80 & 70.77 & 70.80 & 70.80 & 70.80 & 69.57 & 70.80 & 70.80 & 69.57 & 69.57 & 68.87 & 68.87 & 66.36 & 71.25 & 71.25 & 71.25 & 70.87 & \begin{tabular}{|l|l|}
65.17 \\
\end{tabular} & 72.37 & 99.52 & \\
\hline
\end{tabular}




\section{Discussion}

Avian pox viruses have been isolated from a wide range of avian species including commercial poultry, wild and pet birds. Poxvirus infection is suspected when proliferative skin and/or oral and tracheal lesions are observed. In such cases, a diagnosis is made by histopathology examination of the lesions. Fowl pox vaccine is used in Iranian poultry industry in layer and breeder farms. We don't have any specific vaccine for pet birds. Canary pox has been known as the disease that can result in high losses in a short time, as a reemerging disease that has not been present during recent years in canary flocks in Iran (12).

Most of our knowledge about the situation of APVs in Iran was obtained from very few reports concerning the epidemiology and the infection biology of the virus. In this study, APVs in clinical cases of affected commercial chickens, turkeys, and canary were identified and characterized by molecular methods to determine the etiology of APV in Iran, 2012. As for the molecular biological analysis, gene $\mathrm{P} 4 \mathrm{~b}$ amplification products of the expected size were obtained for all the strains of this study, thus confirming that PCR is an extremely valuable diagnostic method for APV infections. Phylogenetic relationships of Avipoxviruses have been analyzed based on the gene corresponding to vaccinia virus (VACV) P4b (fpv167, VACV A3L), indicating that all Avipoxvirus strains cluster into 3 major clades, namely, A (Fowl pox (FWPV)-like), B (Canary pox (CNPV)-like) and C (Psittacine). Clade A can be further divided into seven sub clades (A1-A7) and Clade B is comprised of three sub clades (B1-B3) (14). Based on the phylogenetic analysis of four conserved regions, the viruses characterized from Iranian columbiformes cluster into two groups. The viruses from turkey and commercial chickens grouped in sub clade $\mathrm{A} 1$ and the viruses from canary grouped in sub clade B1. Conversely, it has also been shown that the same viruses can infect different birds. Therefore, in this study as well as in others, APVs from the same species of bird are classified in different sub clades $(4,13,14)$. Fasaei et al (2014) in phylogenetic analysis of Avipoxvirus strains isolated from different bird species in Iran showed that a similarity of $71-100 \%$ with the other sequences in the GenBank but they didn't submit their sequences in GenBank and didn't determine the clade of isolates (3). The research which did by Gholami-Ahangaran (2014) on avian pox of backyard poultry in Iran indicated that $66.1 \%$ and $80.7 \%$ of samples were positive for avian pox virus on histopathological and PCR examination, respectively (8).

The data presented in this research provide novel insights into the molecular characterization of avian pox viruses collected from the broad host range outbreaks in different geographical parts of Iran on particular period time.

\section{Acknowledgment:}

The authors would like to acknowledge PCR Veterinary Diagnostic Laboratory experts for their technical assistance. The authors declare that they have no conflict of interest.

\section{References}

1. Knipe DM, Howley PM. Fields virology. $6^{\text {th }}$ ed. Philadelphia : Wolters Kluwer/Lippincott Williams \& Wilkins Health, 2013.

2. OIE. Manual of diagnostic tests and vaccines for terrestrial animals. $6^{\text {th }}$ ed. Paris : Office International des Epizooties, 2008: 1092-106.

3. Fasaei N, Madadgar B, Langeroodi OA, Ghafari M. Molecular detection and phylogenetic analysis of Avipoxvirus strains isolated from different bird species. Iranian J Vet Res 2014; 15(1): 40-4.

4. Manarolla G, Pisoni G, Sironi G, Rampin T. Molecular biological characterization of avian poxvirus strains isolated from different avian species. Vet Microbiol 2010; 140(1): 1-8.

5. Pérez-Tris J, Williams R, Abel-Fernández E, et al. A multiplex PCR for detection of poxvirus and papillomavirus in cutaneous warts from live birds and museum skins. Avian Dis 2011; 55(4): 545-53.

6. Ebrahimi M, Shahsavandi S, Masoudi S, Ghodsian N, Hablalvarid M, Hatami A. Development of a multiplex polymerase chain reaction for differential diagnosis of canary pox virus. Iranian J Virol 2014; 6(3): 19-23.

7. Jarmin S, Manvell R, Gough RE, Laidlaw SM, Skinner MA. Avipoxvirus phylogenetics: identification of a PCR length polymorphism that discriminates between the two major clades. J Gen Virol 2006; 87(8): 2191-201.

8. Gholami-Ahangaran M, Zia-Jahromi N, 
Namjoo A. Molecular detection of avian pox virus from nodular skin and mucosal fibrinonecrotic lesions of Iranian backyard poultry. Trop Anim Health Prod 2014; 46(2): 349-53.

9. Lee LH, Lee KH. Application of the polymerase chain reaction for the diagnosis of fowl poxvirus infection. J Virol Methods 1997; 63(1): 113-9.

10. Tamura K, Peterson D, Peterson N, Stecher G, Nei M, Kumar S. MEGA5: molecular evolutionary genetics analysis using maximum likelihood, evolutionary distance, and maximum parsimony methods. Mol Biol Evol 2011; 28(10): 2731-9.

11. Offerman K, Carulei O, Gous T, Douglass AN, Williamson AL. Phylogenetic and histological variation in avipoxviruses isolated in South Africa. J Gen Virol 2013; 94(10): 2338-51.

12. Kheirandish R, Askari N, Salehi M. Clinical and pathological findings of concurrent poxvirus lesions and aspergillosis infection in canaries. Asian Pac J Trop Biomed 2013; 3(3): 182-5.

13. Illera JC, Emerson BC Richardson DS. Genetic characterization, distribution and prevalence of avian pox and avian malaria in the Berthelot's pipit (Anthus berthelottis) in Macaronesia. Parasitol Res 2008; 103: 1435-43.

14. Gyuranecz M, Foster JT, Dan A, et al. Worldwide phylogenetic relationship of avian poxviruses. J Virol 2013; 87(9): 4938-51.

\section{MOLEKULARNA KARAKTERIZACIJA IN FILOGENETSKA ANALIZA AVIARNEGA VIRUSA POX, IZOLIRANEGA PRI PETIH VRSTAH PTIC V KOMERICIALNIH JATAH V IRANU}

\section{A. Ghalyanchilangeroudi, H. Hosseini, R. Morshed}

Povzetek: Osepnice ptic (AP, iz angl. avian pox) so virusna bolezen, ki lahko okužijo veliko različnih vrst ptic. Cilj predstavljene raziskave je bila molekularna identifikacija in karakterizacija izoliranih virusov pox, pridobljenih iz krast ljubiteljskih ptic in farmskih ptic v Iranu, s pomočjo metode PCR. Vzorci krast s področja sprememb na koži in sluznicah je bil zbran pri petih pacientih s kliničnimi znaki bolezni. S pomočjo metode PCR je bil pomnožen 578 baznih parov dolg odsek gena poxvirusa 4b. To ohranjeno območje poxvirusa je pomembno za določitev genskih razmerij med virusi, zato je bilo doloćeno zaporedje DNK za nadaljne analize. Iranska izolata Avipoxvirusa objavljena v tej študiji sta bila razvrščena v razred A1 (komercialne piščančje in puranje jate) in B1 (kanarčki). Za boljše razumevanje molekularne karakterizacije iranskih sevov virusa AP bo potrebno opraviti nadaljnje študije. 